\title{
Effect of Growth Regulators and Methods of Application on Vegetative Growth and Spike Yield of Tuberose (Polianthes tuberosa L.) cv. 'Suvasini'
}

\author{
T. Suseela ${ }^{1}$, V. Vijaya Bhaskar ${ }^{2}$ and R. Chandrasekhar ${ }^{3}$ \\ ${ }^{1}$ Department of Floriculture and Landscape Architecture, Dr. Y. S. R. Horticultural \\ University, College of Horticulture, Venkataramannagudem - 534 101, West Godavari \\ District, Andhra Pradesh, India \\ ${ }^{2}$ Department of Floriculture and Landscape Architecture, College of Horticulture, \\ Anantharajupeta - 516 105, Kadapa district, Andhra Pradesh, India \\ ${ }^{3}$ Controller of Examinations, SKLTS Horticultural University, Rajendranagar, Hyderabad, \\ Telangana, India \\ *Corresponding author
}

\section{A B S T R A C T}

\begin{tabular}{|l|}
\hline Ke y w o r d s \\
$\mathrm{GA}_{3}$, Growth, \\
$\mathrm{NAA}$, \\
Paclobutrazol, \\
Spike yield, TIBA \\
and tuberose \\
\hline Article Info \\
\hline Accepted: \\
28 December 2017 \\
Available Online: \\
10 February 2018 \\
\hline
\end{tabular}

\section{Introduction}

Flowers are an integral part of human life due to their diversity in beauty, form, texture, colour and fragrance. Tuberose (Polianthes tuberosa L.) is a commercial flowering bulbous plant popularly known as Rajnigandha (Bengali), Gu-e-chari (Hindi), and Nela sempangi in Telugu. Tuberose is
An investigation was carried out to find out the effect of different plant growth regulators by foliar spray and dipping treatment on growth and spike yield of tuberose cv. Suvasini. Experiment was conducted in a two factorial randomized block design with four growth regulators each at two concentrations and two methods of application. Application of $\mathrm{GA}_{3}$ at the rate of $250 \mathrm{ppm}$ recorded significantly early sprouting and lowest number of days required to reach to $50 \%$ sprouting of bulbs. Among different methods of application foliar spray recorded significantly maximum vegetative growth, early flowering, improved quality and higher yield in comparison to dipping method. Application of $\mathrm{GA}_{3}$ at $250 \mathrm{ppm}$ concentration through foliar spray recorded significantly highest number of leaves (137.62), leaf area index (5.10), lowest number of days to reach to $50 \%$ spike emergence (100.35), longest spike length $(103.77 \mathrm{~cm})$, spike weight $(93.25 \mathrm{~g})$, number of florets per spike (64.34) and yield of spikes per hectare (3.42 lakhs/ha). Thus, foliar spraying of $\mathrm{GA}_{3}$ at $250 \mathrm{ppm}$ concentration proved to be ideal to realize higher spike yield in tuberose. 
apart from its better keeping quality. Quality of tuberose flower is considered to be affected by various pre and post-harvest factors such as temperature, relative humidity, frequency of irrigation, nutrition and time of picking the flowers. Over whelming response of growth regulators in regulating the growth and yield of flowers in floriculture is well recognized. Plant growth substances play a pivotal role in the overall performance of plant growth, flower yield and bulb production (Biswas et al., 1983). The present investigation was undertaken to elucidate the effect of different plant growth regulators at different concentrations through different methods of their application to find out their influence on vegetative growth and spike yield in tuberose cv. Suvasini.

\section{Materials and Methods}

The present study was carried out at College of Horticulture, Venkataramannagudem, West Godavari district of Andhra Pradesh during the period from 2012 - 2014. The experiment was conducted with two factors in a randomized block design. Factor-I was consisting of four growth regulators each at two different concentrations viz., NAA 150 ppm $\left(\mathrm{G}_{1}\right)$, NAA $250 \mathrm{ppm}\left(\mathrm{G}_{2}\right), \mathrm{GA}_{3} 150 \mathrm{ppm}$ $\left(\mathrm{G}_{3}\right), \mathrm{GA}_{3} 250 \mathrm{ppm}\left(\mathrm{G}_{4}\right)$, TIBA $50 \mathrm{ppm}\left(\mathrm{G}_{5}\right)$, TIBA 100 ppm $\left(\mathrm{G}_{6}\right)$, PBZ (Paclobutrazol) 50 $\operatorname{ppm}\left(\mathrm{G}_{7}\right)$ and PBZ 100 ppm $\left(\mathrm{G}_{8}\right)$; while Factor-II was consisting of two methods of application of growth regulators viz., Dipping method $\left(\mathrm{M}_{1}\right)$ and Foliar spray method $\left(\mathrm{M}_{2}\right)$ of application, thus altogether 16 treatment combinations were replicated thrice. Solutions of $\mathrm{GA}_{3} 150 \mathrm{ppm}$ and $250 \mathrm{ppm}$, NAA $150 \mathrm{ppm}$ and $250 \mathrm{ppm}$ and TIBA 50 ppm and $100 \mathrm{ppm}$ were prepared by dissolving calculated quantity of chemicals in small quantity of ethyl alcohol and volume was made up to one liter. Paclobutrazol 50 ppm and 100 ppm solutions were prepared by dissolving calculated quantity of chemical in distilled water and volume was made up to one liter. Teapol $(0.2 \mathrm{ml} / \mathrm{L})$ was used as surfactant. The treatments were imposed as dipping of bulbs for 12 hours separately in the respective treatment solutions before planting. Bulbs dipped in growth regulator solutions were air dried and used for planting at a spacing of $30 \mathrm{~cm} \times 30 \mathrm{~cm}$ with a depth of $4 \mathrm{~cm}$. Bulbs sown without dipping in the growth regulator solutions were applied through foliar sprays at 30,60 and 90 days after planting. Data were collected on different vegetative growth and yield parameters viz., number of days taken for sprouting of bulbs, time taken for sprouting of $50 \%$ bulbs, number of leaves produced, leaf area index and total chlorophyll content in SPAD units at crop maturity stage.

Number of days were counted for spike emergence and floret opening. Spike length was measured when one or two basal pair of florets were opened with the help of meter scale and expressed in centimetres and spike weight was measured and expressed in grams. Number of florets per spike on an individual spike was recorded just after harvesting of spikes. Yield of flower spikes per hectare was calculated by converting the average number of spikes per plant multiplied by total number of plants in one hectare. The data arrived was subjected to statistical analysis of variance for Factorial Randomized Block Design (F.R.B.D) as described by Panse and Sukhatme (1985).

\section{Results and Discussion}

Data presented in Table 1 indicated significant differences for sprouting of bulbs. Dipping of bulbs in $\mathrm{GA}_{3}$ at $150 \mathrm{ppm}$ recorded significantly lowest number of days taken for sprouting of bulbs (5.33 days) and 50\% sprouting of bulbs (8.85 days) followed by NAA at 150 ppm (10.70 days and 14.05 days respectively). Presence of free $\mathrm{GA}_{3}$ helps in 
breaking down the reserve food material by hydrolytic enzymes, thereby recorded early sprouting with enough moisture (Kumar and Singh, 2005). Application of $\mathrm{GA}_{3}$ and NAA to the bulbs of tuberose through dippping method reduced the level of inhibitors thereby leading to early sprouting which also helped in breaking the dormancy of bulbs and thus promoted cell division and cell elongation in the apical meristematic tissue. Similar kind of observation was reported earlier in gladiolus corm sprouting by Tripathi et al., (2009) and in tuberose by Kumar et al., (2011) and Wagh et al., (2012).

The data presented in Table 1 has revealed significant differences in the number of leaves produced per plant and the leaf area index at maturity. Among the growth regulators, application of $\mathrm{GA}_{3}$ at $250 \mathrm{ppm}$ recorded significantly highest number of leaves produced per plant (128.81) and leaf area index (4.87) followed by $\mathrm{GA}_{3}$ at 150 ppm. Between the methods of application, foliar spraying of growth regulators recorded significantly highest number of leaves produced per plant (96.44) and leaf area index (3.22) in comparison to dipping method. Interaction effect between growth regulators and methods of application recorded significant differences in the number of leaves produced per plant and leaf area index. Among the combination treatments, foliar spraying of $\mathrm{GA}_{3}$ at $250 \mathrm{ppm}$ recorded significantly highest number of leaves produced per plant (137.62) and leaf area index (5.10) followed by dipping with $\mathrm{GA}_{3}$ at $250 \mathrm{ppm} \quad(120.00$ and 4.65 respectively). Application of $\mathrm{GA}_{3}$ through foliar application induced cell division and cell elongation in the plant tissue thus recorded significantly highest number of leaves produced per plant and highest leaf area index. Gibberellins play an instrumental role in the abolition of apical dominance and thus aid in cell elongation thereby improved the vegetative growth in tuberose. Similar kind of observation has been reported earlier by Kumar et al., (2011) and Wagh et al., (2012) in tuberose.

Significant changes have been noticed in the total chlorophyll content of leaves at maturity by application of different growth regulators through different methods of application (Table 2). Among the growth regulators, application of TIBA at 100 ppm concentration recorded significantly lowest total chlorophyll content (44.45 SPAD) followed by TIBA at $50 \mathrm{ppm}$ concentration in the leaf tissue, whereas, significantly highest total chlorophyll content was observed by application of PBZ at $100 \mathrm{ppm}$ concentration (70.95 SPAD) followed by application of PBZ at 50 ppm concentration. Between methods of application, foliar spraying of growth regulators recorded significantly highest total chlorophyll content in the leaf tissue (58.0 SPAD) compared to dipping method. Interaction effect between the growth regulators and methods of application was found significant. Foliar application of PBZ at 100 ppm concentration recorded significantly highest total chlorophyll content (73.71 SPAD) followed by application of PBZ at 100 ppm concentration through dipping method.

Dark green colour appearance of leaves has been correlated with increased total chlorophyll content (Sankhla et al., 1985). Kulkarni et al., (1995) and Zaky et al., (1999) also supported the statement made by Sankhla et al., (1985). Foliar spraying of plant growth retardants (antigibberillin/dwarfing agents) enhanced the chlorophyll content of leaves which helped to increase the functional life of source for a longer period leading to improved photosynthetic efficiency thereby enhanced the accumulation of photo assimilates in the plant (Kumar et al., 2006). 
Table.1 Effect of growth regulators and methods of application on vegetative growth parameters of tuberose cv. Suvasini

\begin{tabular}{|c|c|c|c|c|c|c|c|c|c|c|c|c|}
\hline \multirow{3}{*}{$\begin{array}{l}\text { Growth } \\
\text { regulator } \\
\text { (G) }\end{array}$} & \multicolumn{12}{|c|}{ Method of application (M) } \\
\hline & \multicolumn{3}{|c|}{$\begin{array}{c}\text { Days to sprouting of } \\
\text { bulbs }\end{array}$} & \multicolumn{3}{|c|}{$\begin{array}{c}\text { Days to } 50 \% \text { sprouting of } \\
\text { bulbs }\end{array}$} & \multicolumn{3}{|c|}{$\begin{array}{c}\text { Number of leaves at } \\
\text { maturity }\end{array}$} & \multicolumn{3}{|c|}{$\begin{array}{l}\text { Leaf area index at } \\
\text { maturity }\end{array}$} \\
\hline & $\begin{array}{c}\text { Dipping } \\
\left(\mathbf{M}_{1}\right)\end{array}$ & $\begin{array}{c}\text { Foliar } \\
\text { spray } \\
\left(\mathrm{M}_{2}\right)\end{array}$ & Mean & $\begin{array}{c}\text { Dipping } \\
\left(\mathbf{M}_{1}\right)\end{array}$ & $\begin{array}{c}\text { Foliar } \\
\text { spray } \\
\left(\mathbf{M}_{2}\right)\end{array}$ & Mean & $\begin{array}{c}\text { Dipping } \\
\left(\mathbf{M}_{1}\right)\end{array}$ & $\begin{array}{c}\text { Foliar } \\
\text { spray } \\
\left(\mathbf{M}_{2}\right)\end{array}$ & Mean & $\begin{array}{c}\text { Dipping } \\
\left(\mathbf{M}_{1}\right)\end{array}$ & $\begin{array}{c}\text { Foliar } \\
\text { spray } \\
\left(\mathbf{M}_{2}\right)\end{array}$ & Mean \\
\hline NAA 150 & 10.70 & - & - & 14.05 & - & - & 100.33 & 103.45 & 101.94 & 3.21 & 3.55 & 3.38 \\
\hline NAA 250 & 14.80 & - & - & 20.70 & - & - & 93.71 & 96.48 & 95.10 & 3.19 & 3.32 & 3.25 \\
\hline $\mathrm{GA}_{3} 150$ & 5.33 & - & - & 8.85 & - & - & 111.42 & 114.71 & 113.06 & 3.50 & 3.64 & 3.57 \\
\hline $\mathrm{GA}_{3} 250$ & 12.45 & - & - & 18.35 & - & - & 120.00 & 137.62 & 128.81 & 4.65 & 5.10 & 4.87 \\
\hline TIBA 50 & 15.00 & - & - & 23.95 & - & - & 92.14 & 96.45 & 94.30 & 2.51 & 2.90 & 2.70 \\
\hline TIBA 100 & 16.75 & - & - & 26.60 & - & - & 73.70 & 75.33 & 72.72 & 2.02 & 2.95 & 2.48 \\
\hline PBZ 50 & 16.50 & - & - & 27.85 & - & - & 71.25 & 75.59 & 73.42 & 2.33 & 2.42 & 2.37 \\
\hline PBZ 100 & 18.15 & - & - & 28.75 & - & - & 67.70 & 69.85 & 70.70 & 1.86 & 1.89 & 1.87 \\
\hline Mean & 13.71 & - & - & 21.14 & - & - & 90.90 & 96.44 & & 2.90 & 3.22 & \\
\hline Factor & SEd \pm & & D at $5 \%$ & SEd \pm & & at $5 \%$ & SEd $\_$ & & at $5 \%$ & SEd \pm & & at $5 \%$ \\
\hline G & 0.35 & & 0.74 & 0.68 & & .43 & 1.18 & & 2.50 & 0.013 & & 0.027 \\
\hline $\mathbf{M}$ & 0.35 & & 0.74 & 0.68 & & .43 & 0.34 & & 0.72 & 0.013 & & 0.027 \\
\hline $\mathbf{G} \times \mathbf{M}$ & - & & - & - & & - & 1.67 & & 3.53 & 0.031 & & 0.082 \\
\hline
\end{tabular}


Table.2 Effect of growth regulators and methods of application on physiological and floral parameters of tuberose cv. Suvasini

\begin{tabular}{|c|c|c|c|c|c|c|c|c|c|}
\hline \multirow{3}{*}{$\begin{array}{l}\text { Growth } \\
\text { regulator } \\
\text { (G) }\end{array}$} & \multicolumn{9}{|c|}{ Method of application (M) } \\
\hline & \multicolumn{3}{|c|}{$\begin{array}{c}\text { Total chlorophyll content at } \\
\text { maturity }\end{array}$} & \multicolumn{3}{|c|}{ Days to $50 \%$ floret opening } & \multicolumn{3}{|c|}{ Days to $50 \%$ spike emergence } \\
\hline & $\begin{array}{l}\text { Dipping } \\
\left(\mathbf{M}_{1}\right)\end{array}$ & $\begin{array}{c}\text { Foliar } \\
\text { spray } \\
\left(\mathbf{M}_{2}\right)\end{array}$ & Mean & $\begin{array}{l}\text { Dipping } \\
\left(\mathbf{M}_{1}\right)\end{array}$ & $\begin{array}{c}\text { Foliar } \\
\text { spray } \\
\left(\mathbf{M}_{2}\right)\end{array}$ & Mean & $\begin{array}{l}\text { Dipping } \\
\left(\mathbf{M}_{1}\right)\end{array}$ & $\begin{array}{c}\text { Foliar } \\
\text { spray } \\
\left(\mathbf{M}_{2}\right)\end{array}$ & Mean \\
\hline NAA 150 & 52.78 & 55.82 & 54.30 & 142.96 & 138.25 & 140.61 & 175.85 & 169.25 & 172.55 \\
\hline NAA 250 & 53.45 & 57.36 & 55.41 & 108.89 & 101.61 & 105.25 & 178.46 & 160.46 & 169.46 \\
\hline $\mathbf{G A}_{3} 150$ & 55.05 & 57.10 & 56.08 & 103.55 & 97.95 & 100.75 & 115.95 & 108.95 & 112.45 \\
\hline $\mathrm{GA}_{3} 250$ & 56.44 & 59.55 & 58.00 & 102.23 & 96.73 & 99.48 & 103.30 & 100.30 & 101.80 \\
\hline TIBA 50 & 45.39 & 48.41 & 46.90 & 154.00 & 150.00 & 152.00 & 184.46 & 180.85 & 182.66 \\
\hline TIBA 100 & 42.19 & 46.71 & 44.45 & 160.56 & 156.84 & 158.70 & 200.00 & 196.25 & 198.13 \\
\hline PBZ 50 & 61.39 & 65.41 & 63.40 & 95.75 & 89.75 & 92.75 & 144.84 & 134.34 & 139.59 \\
\hline PBZ 100 & 68.19 & 73.71 & 70.95 & 85.56 & 75.70 & 80.78 & 128.01 & 121.01 & 124.51 \\
\hline Mean & 54.36 & 58.00 & & 119.23 & 113.40 & & 151.60 & 146.42 & \\
\hline Factor & SEd \pm & & t $5 \%$ & SEd \pm & & CD at $5 \%$ & SEd \pm & & $\mathrm{CD}$ at $5 \%$ \\
\hline$\overline{\mathbf{G}}$ & 0.51 & & 08 & 1.14 & & 2.43 & 0.84 & & 1.78 \\
\hline $\mathbf{M}$ & 0.25 & & 54 & 0.57 & & 1.21 & 0.84 & & 1.78 \\
\hline$\overline{G \times M}$ & 0.72 & & 52 & 1.61 & & 3.42 & 2.37 & & 5.03 \\
\hline
\end{tabular}


Table.3 Effect of growth regulators and methods of application on spike yield parameters of tuberose cv. Suvasini

\begin{tabular}{|c|c|c|c|c|c|c|c|c|c|c|c|c|}
\hline \multirow{3}{*}{$\begin{array}{l}\text { Growth } \\
\text { regulator } \\
\text { (G) }\end{array}$} & \multicolumn{12}{|c|}{ Method of application (M) } \\
\hline & \multicolumn{3}{|c|}{ Spike length (cm) } & \multicolumn{3}{|c|}{ Spike weight (g) } & \multicolumn{3}{|c|}{$\begin{array}{c}\text { Number of florets per } \\
\text { spike }\end{array}$} & \multicolumn{3}{|c|}{ Spike yield/hectare (lakhs) } \\
\hline & $\begin{array}{c}\text { Dipping } \\
\left(\mathbf{M}_{1}\right)\end{array}$ & $\begin{array}{c}\text { Foliar } \\
\text { spray } \\
\left(\mathbf{M}_{2}\right)\end{array}$ & Mean & $\begin{array}{c}\text { Dipping } \\
\left(\mathbf{M}_{1}\right)\end{array}$ & $\begin{array}{c}\text { Foliar } \\
\text { spray } \\
\left(\mathbf{M}_{2}\right)\end{array}$ & Mean & $\begin{array}{c}\text { Dipping } \\
\left(\mathbf{M}_{1}\right)\end{array}$ & $\begin{array}{c}\text { Foliar } \\
\text { spray } \\
\left(\mathbf{M}_{2}\right)\end{array}$ & Mean & $\begin{array}{c}\text { Dipping } \\
\left(\mathbf{M}_{1}\right)\end{array}$ & $\begin{array}{c}\text { Foliar } \\
\text { spray } \\
\left(\mathbf{M}_{2}\right)\end{array}$ & Mean \\
\hline NAA 150 & 80.77 & 83.97 & 82.37 & 90.42 & 90.55 & 90.48 & 43.34 & 47.96 & 45.65 & 2.31 & 2.62 & 2.46 \\
\hline NAA 250 & 79.13 & 83.30 & 81.21 & 88.46 & 89.25 & 88.85 & 44.15 & 46.50 & 45.32 & 2.10 & 2.50 & 2.30 \\
\hline $\mathrm{GA}_{3} 150$ & 85.79 & 90.38 & 88.10 & 92.75 & 92.86 & 92.80 & 50.36 & 52.50 & 51.43 & 2.73 & 2.76 & 2.75 \\
\hline $\mathbf{G A}_{3} 250$ & 94.38 & 103.77 & 99.10 & 92.98 & 93.25 & 93.12 & 57.13 & 64.39 & 60.76 & 3.24 & 3.42 & 3.33 \\
\hline TIBA 50 & 77.08 & 74.95 & 76.01 & 83.90 & 83.98 & 83.94 & 36.67 & 38.00 & 37.30 & 1.63 & 1.57 & 1.60 \\
\hline TIBA 100 & 73.14 & 71.25 & 72.20 & 83.76 & 83.84 & 83.80 & 38.25 & 40.50 & 39.38 & 1.43 & 1.51 & 1.47 \\
\hline PBZ 50 & 47.98 & 49.48 & 48.73 & 83.00 & 83.56 & 83.28 & 32.42 & 34.25 & 33.34 & 0.85 & 0.96 & 0.90 \\
\hline PBZ 100 & 41.54 & 43.64 & 42.59 & 83.60 & 83.68 & 83.64 & 26.00 & 28.00 & 27.00 & 1.05 & 1.14 & 1.09 \\
\hline Mean & 72.11 & 75.34 & & 87.36 & 87.62 & & 41.03 & 44.00 & & 1.94 & 2.04 & \\
\hline Factor & SEd- & & at $5 \%$ & SEd \pm & & at $5 \%$ & SEd \pm & & at $5 \%$ & SEd \pm & & CD at $5 \%$ \\
\hline $\mathbf{G}$ & 0.58 & & 1.23 & 0.74 & & .57 & 1.54 & & 3.27 & 0.05 & & 0.11 \\
\hline $\mathbf{M}$ & 0.29 & & 0.62 & 0.37 & & V.S & 0.77 & & 1.64 & 0.03 & & 0.06 \\
\hline$\overline{G \times M}$ & 0.82 & & 1.75 & 4.90 & & N.S & 2.18 & & 4.63 & 0.07 & & 0.16 \\
\hline
\end{tabular}


The analyzed data has revealed significant differences in the physiological and floral parameters (Table 2). Among the growth regulators, application of PBZ 100 ppm recorded significantly lowest number of days taken to $50 \%$ floret opening (80.78 days) followed by $\mathrm{PBZ}$ at $50 \mathrm{ppm}$, whereas, application of TIBA at $100 \mathrm{ppm}$ recorded significantly highest number of days taken to $50 \%$ floret opening (158.70) followed by TIBA at $50 \mathrm{ppm}$. Between the methods of application, foliar spraying of growth regulators recorded significantly lowest number of days taken to $50 \%$ floret opening (113.40 days) in comparison to dippping method of application. Interaction effect between growth regulators and methods of application recorded significant differences for days to $50 \%$ floret opening. Foliar spraying of paclobutrazol at $100 \mathrm{ppm}$ concentration recorded significantly lowest number of days to $50 \%$ floret opening (75.70 days) followed by application of paclobutrazol at $100 \mathrm{ppm}$ through dippping method. Among the growth regulators, application of $\mathrm{GA}_{3}$ at $250 \mathrm{ppm}$ concentration recorded significantly lowest number of days taken to $50 \%$ flower spike emergence (101.80 days) followed by $\mathrm{GA}_{3}$ at $150 \mathrm{ppm}$ concentration, whereas, application of TIBA at $100 \mathrm{ppm}$ concentration recorded significantly highest number of days taken to $50 \%$ flower spike emergence (198.13 days) followed by TIBA at $50 \mathrm{ppm}$ concentration. Between the methods of application, foliar spraying of growth regulators recorded significantly lowest number of days to $50 \%$ flower spike emergence (146.42 days) compared to dipping method. Interaction effect between growth regulators and methods of application recorded significant differences in the flower spike emergence. Foliar application of $\mathrm{GA}_{3}$ at $250 \mathrm{ppm}$ concentration recorded significantly lowest number of days to $50 \%$ spike emergence (100.30 days) followed by foliar application of $\mathrm{GA}_{3}$ at $250 \mathrm{ppm}$ concentration. Padaganuru et al., (2005) explained that exogenous application of $\mathrm{GA}_{3}$ enhanced the induction of floral bud break by differentiation of vegetative primordia to floral primordia in the apical meristem there by induced the early spike emergence and floret opening.

Significant differences were observed in the spike yield parameters of tuberose cv. Suvasini by application of different plant growth regulators through different methods of application (Table 3). Among the plant growth regulators, application of $\mathrm{GA}_{3}$ at 250 ppm concentration recorded significantly highest spike length $(99.10 \mathrm{~cm})$, spike weight (93.12 g), number of florets per spike (60.76) and spike yield (3.33 lakhs/ha) followed by $\mathrm{GA}_{3}$ at $150 \mathrm{ppm}$ concentration, whereas, significantly lowest spike length $(42.59 \mathrm{~cm})$, number of florets per spike (27.00) were recorded with application of paclobutrzol at 100 ppm concentration. However, significantly lowest spike weight $(83.28 \mathrm{~g})$ and spike yield (0.90 lakhs/ha) were observed with PBZ at 50 ppm concentration. Significant differences were observed between the methods of application of growth regulators. Foliar application of growth regulators recorded significantly highest spike length $(75.34 \mathrm{~cm})$, number of florets per spike (44.00) and spike yield (2.04 lakhs /ha). Spike weight was found non-significant with methods of application of growth regulators. The interaction effect between growth regulators and methods of application was found significant. Foliar application of $\mathrm{GA}_{3}$ at 250 concentration recorded significantly highest spike length $(103.77 \mathrm{~cm})$, number of florets per spike (64.39) and spike yield (3.42 lakhs/ha), whereas, dipping of bulbs in paclobutrazol at $100 \mathrm{ppm}$ concentration recorded significantly lowest spike length $(41.54 \mathrm{~cm})$, number of florets per spike (26.00) and spike yield 
(1.05 lakhs/ha). Spike weight was found nonsignificant with the interaction of growth regulators and methods of application. Sarkar et al., (2009) observed that application of growth promoting compounds showed a significant effect on the promotion of vegetative growth and accumulation of plant biomass due to marginal increase in chlorophyll content which contributed to enhanced photosynthetic efficiency in the plant. Increased spike length, spike weight, number of florets per spike and spike yield with foliar spray of $\mathrm{GA}_{3}$ at $250 \mathrm{ppm}$ concentration was mainly due to an increase in the cell division and cell elongation in the intercalary tissue. Further, it is an established fact that application of $\mathrm{GA}_{3}$ promotes increased number of leaves with maximum leaf area which contributes to production and accumulation of more photosynthates. Thus, increased accumulation of photo-assimilates in the plant might have been translocated towards the reproductive organs of the plant for development of floral organs.

Based on the result obtained, it could be concluded that foliar application of growth regulators was found better than dipping of bulbs in the growth regulator solutions. Foliar application of growth regulators at regular interval might have supplied the required stimulus for cell division, cell elongation and differentiation. Therefore, it is suggested that application of plant growth regulators through foliar spray is better to increase the plant growth and spike yield than dipping the bulbs in growth regulator solutions as it may not provide the required stimulus for the meristematic tissue differentiation during the critical stages of crop development.

\section{References}

Biswas, J., Bose, J.K. and Matti. R.G. 1983. Effect of growth substances on growth and flowering of tuberose (Polinathes tuberosa L). South Indian Horticulture. 31(2/3): 129-132.

Kulkarni, S.S., Chetti, M.B. and Uppar, D.S. 1995. Influence of growth retardants on biochemical parameters in sunflower. Journal of Maharashtra Agricultural Universities. 29: 352-354.

Kumar, J., Tapendra, S. and Krishan, P. 2011. Effect of $\mathrm{GA}_{3}$ and VAM on growth and flowering in tuberose (Polianthes tuberosa L.) cv. Double, Agricultural Science Digest. 31(4): 289-292.

Kumar, P., Hiremath, S.M. and Chetti, M.B. 2006. Influence of growth regulators on dry matter production and distribution and shelling percentage in determinate and semi-determinate and semi-determinate soybean genotype. Legume Research. 29: 191-195.

Kumar, V. and Singh, R.P. 2005. Effect of soaking of mother corms with plant growth regulators on vegetative growth flowering and corm production in gladiolus. Journal of Ornamental Horticulture (New Series). 8(4): 306308.

Padaganur, V.G., Mokashi, A.N. and Patil, V.S. 2005. Effect of growth regulators on growth and yield of tuberose cv. Single. Karnataka Journal of Agricultural Sciences. 18(2): 469-473.

Panse, V.G. and Sukhatme, P.V. 1985. Statistical Methods for Agricultural Workers ICAR, New Delhi, pp. 176.

Sankhla, N., Davis, T.D., Upadhyay, A., Sankhla, D., Walser, R.H. and Smith, B.N. 1985. Growth and metabolism of soybean as affected by paclobutrazol. Plant Cell Physiology. 26: 913-921.

Sarkar, J., Misra, R.L., Sanjay, K., Singh, Prasad, K.V. and Ajay, A. 2009. Effect of growth regulators on growth and flowering in tuberose under north India conditions, Indian Journal of 
Horticulture. 66(4): 502-507.

Tripathi, V.K., Ramesh, B.T., Shukla, H.S., Mishra, A.N. and Pandey, M. 2009. Effect of gibberellic acid, NAA and kinetin on growth, flowering and corn production of gladiolus cv. Sapna. Journal of Asian Horticulture. 5(2): 61-64.

Wagh, V.K., Chawla, S.L., Gaikwad, A.R. and Parolekar, S.S. 2012. Effect of bulb size and $\mathrm{GA}_{3}$ on vegetative and floral characters of tuberose (Polianthes tuberosa L.) cvs.Prajwal and Calcutta Single. Progressive Horticulture. 44(1): 27-31.

Zaky, L.M., El-Bahay, M.M., Dowidar, A.E. and Latif, H.H. 1999. Some physiological studies on the effect of the growth retardant Pix on Vicia faba plant. I. Egyptian Journal of Physiological. 23(3): 335-359.

\section{How to cite this article:}

Suseela, T., V. Vijaya Bhaskar and Chandrasekhar, R. 2018. Effect of Growth Regulators and Methods of Application on Vegetative Growth and Spike Yield of Tuberose (Polianthes tuberosa L.) cv. 'Suvasini'. Int.J.Curr.Microbiol.App.Sci. 7(02): 3617-3625.

doi: https://doi.org/10.20546/ijcmas.2018.702.430 